\title{
Social Security Insurance: Included and Excluded Categories in Terms of Individuals According to Effective Jordanian Labor Laws and Social Security Laws
}

\author{
Dr. HASSAN SAMI ALABADY \\ PhD in Philosophy of Law - Amman Arab University, Jordan. \\ Assistant Professor in Faculty of LAW- Amman Arab University. \\ Dr. SHEREEN N. ABU GHAZALEH \\ $\mathrm{PhD}$ in Philosophy of Law - Aberdeen University, UK. \\ Assistant Professor in Faculty of LAW- Amman Arab University. \\ Email:2017law@gmail.com
}

\begin{abstract}
This research aimed to identify the Labor Law category as being mandatory included by registering at the Jordanian Social Security, and the excluded category in this regard. Therefore, it is important to talk about laborers in relation to the effective labor law and those who have work relations with their employers as well as public employees or servants who are not subject to the civil or military retirement law. In addition, it is important to discuss this issue in relation to the Jordanian laborers who are working at the international and regional missions, diplomatic, political, foreign and Arabic military missions in the Kingdom as well as consulates and their affiliate technical and educational centers. Also, the minor laborers and trainees are included in this discussion as well as the categories excluded from the Jordanian Social Security Law such as house servants and so on.
\end{abstract}

Keywords: Social Security, Insurance, Individuals, Labors Laws, Jordan.

\section{Introduction}

The principles of social security are designed to bring reassurance to all individuals in society, however, considering the difficulty of applying social security laws to the whole population, it may only include a group of categories that can be applicable to the law, especially those who need protection. Little by little, with the development of these social laws, laws are competing to include new categories as well as giving non-binding groups the opportunity to be covered by these laws while allowing them to join the optional social security laws. Social security is essential for every individual. The welfare of society citizens, migrants and all those non-nationals are the basic right of every person living in that specific country (Amin, Aziz, \& Ab Hamid, 2017).

The social function is one of the characteristics of the social security law that is to serve the worker as well as the employer. The worker is ensured that he/she will receive compensation easily and simply. Since 2004, there has been increase in discussion of social security laws in developing countries (Djankov \& Ramalho, 2009). The social security laws also protect the employer through the fact that the Social Security Corporation usually compensates workers for monthly contributions paid by the employer the Social Security Corporation. There is no doubt that the principles of social security are based on the assistance of the weak workers class in order to secure the minimum social protection for them as well as to strengthen the social ties among the members of the society through the organization of class distinctions and not allowing the class of the workers to be exploited by the employers. 
In Jordan, Social Security law was adopted in 2011, titled "The Social Security Law". This law is adopted after replacing the previous law titled "Social Security Temporary Law" of 2010. This study aims to critically examine the labor laws and social security laws of Jordan. This study also aims to identify the mandatory and non-mandatory categories in the respective laws.

\section{Research Methodology}

This research is based on secondary data. The Social Security Law (Act, 2010) and later in in 2014 has been selected for critical examination. This study in particular critically examines the insurance policy in light of the social security law of Jordan. The law was assessed using critical evaluation method of legal research methodology. This method is widely used for evaluation of legal documents (McCrudden, 2017). According to Tyler (2017) a legal research uses two approaches; primary authority of law and secondary authority of law. In primary authority of law, legal documents are review and critically analyzed whereas, in secondary authority of law, the reports and journals issued by non-governmental bodies are analyzed. This research is focused on analysis of legal document issued as an Act by the government, therefore, it focuses on primary authority of law. The social security law has been analyzed for the purpose to identify included and excluded categories to identify the mandatory and non-mandatory composites of this specific law.

Social Security Law (Act) of 2014 comprises of nine chapters and is stretch over 110 articles. The document has been reviewed in detail and based on the purpose of research, it has been divided into categories which are discussed below.

The Social Security Law covers the insurance of workers in terms of the risks they may face. Article 3 of the Social Security Law covers injuries during work, occupational diseases, old age insurance, disability, death, maternity insurance, unemployment insurance, and medical insurance.

However, Article 4 of the Social Security Law stipulates that persons who are subject to the provisions of this law are required to have completed the age of 16 years, but shall not require them to hold Jordanian nationality; this means the law can apply to Jordanians and foreigners. Also, the Article does not require a specific period of the work contract. In addition, there is no requirement for a certain wage to include the individuals by the provisions of the Social Security Law, and certainly, the wage shall not be less than the minimum wage set by the Jordanian legislation that is in the amount of 220 Jordanian dinars monthly. Finally, the Article shows the possibility of covering businesses or works inside and outside of Jordan. In any case, it is not permissible to violate the provisions of the international agreements that regulate the rules of double insurance.

\section{Persons mandatorily covered by the Jordanian Social Security Law}

There are categories of workers and employers who are obliged to join social security. This regulation applies to those who are subject to its provisions once they meet the conditions of submission, even if they do not wish to do so. However, those who fail to meet the conditions of submission shall not be covered by social security and shall be excluded from its provisions, even if they need it. This is provided that they are not in violation of the principle of equality guaranteed by most constitutions. Therefore, legislators are keen not to close the door to excluded groups from being subject to social security. Rather, it provides them the chance to join social security on a voluntary basis upon special terms that reconcile their need for care with the provisions of the law. (Hamdan, 2009, p 343-344).

Others believe that labor should be free to choose to join the retirement program or not, since an individual is seeking his own interest. However, this view is criticized because of its short-sighted behavior and poor planning for dealing with the future risks that need to be addressed by the community. This is the rationale for the comprehensive compulsory programs, and there is no way for voluntary subscription programs as a 
single program. Society needs protection against the short-sightedness of some individuals, where laws need to be enacted to force them to participate in social security. (Al-Zoubi, 2013).

\section{Workers subject to the provisions of the effective Labor Law}

The first category, abiding by the application of the Jordanian Social Security Law, is the workers. Article 4 provides that they are subject to the effective Labor Law. The Jordanian Labor Law defines in Article 2 the worker as follows: "any male or female person who performs work for a specific wage and follows an employer, including minors and those who are under trial or rehabilitation." According to this definition, it is clear to us that workers covered by social security are:

\section{Those who have working relations with the employer}

There must be a bond between the worker and the employer. This association takes the form of a contract. This contract is called the contract of employment, which defines the duties and rights of both the worker and the employer. The aim of the worker is to provide a specific job to the employer for a wage. In the past, it was believed that the work was limited to physical works, i.e. the manual work of the worker, whereas intellectual or mental works were excluded. However, in light of the continuing evolution of labor legislation, it has become obvious to include intellectual works in the Labor Law, such as the work of a university professor, engineer, lawyer, and others. Therefore, some define work as the capacity, self or muscular effort paid by a worker in favor of his employer. (Ramadan, 2014).

\section{The presence of the dependency cause of the worker towards the employer}

Article 2 of the Jordanian Labor Law defines the contract of employment as follows: "an explicit or implicit verbal or written agreement, whereby the employee undertakes to work for and under his employer's supervision or management for a specific wage." On the above definition, we find that the element of dependency is clear, which means that the worker shall work under the management and supervision and control of his employer, i.e. the worker dependent (minor) and the employer is independent or major.

Article 2 of the Social Security Law defines the employer as: "any natural or legal person employing one or more persons subject to the provisions of this law."

Of course, if the element of dependency is lost, i.e. the worker performs his or her work without dependence on their employer, he or she shall lose the worker's description and the Labor Law shall not apply to him or her, and he or she shall not meet the description determined by the Social Security Law for those workers subject to the provisions of the Labor Law.

\section{They are paid for their works}

Article 2 of the Jordanian Social Security Law provides that the remuneration or wage is "the cash money equivalent or in-kind remuneration paid to the insured for his or her work in accordance with the rules determined by the regulations issued under the provisions of this law."

Also, Article 2 of the Labor Law stipulates that: "All that the worker is entitled to for his work in cash or in kind in addition to any other benefits of any kind, provided by the law, the employment contract or due to the articles of association are considered practically payable except due wages for overtime work." On the above Article, we conclude that the wage is the financial remuneration charged by the worker for his efforts on his physical or mental work. However, usually wages are paid to the worker in cash, but legislation has done well to include wages in kind and considered it as wages such as food, drink, housing, traveling expenses and other types of in-kind wages. 
The provision of this Article has included the concept of wage as other benefits including bonus, gift, grant, the share of profits and allowances. However, legislation has excluded from the concept of wage Overtime, which is the assigned work usually done by the worker for the employer outside working hours, during public holidays or weekends. Article 56 of the Jordanian Labor Law defines working hours as follows:

A. "A worker shall not work more than eight hours a day or forty-eight hours per week except in the cases provided for in this Law and by excluding the break time allocated for eating and rest.

B. The maximum limit for weekly work hours and rest periods shall be allocated so that it shall not exceed eleven hours per day."

In addition, Article 1 of the Overtime Work Instructions issued by Executive Committee Decision No. (3/2015) stipulates that: "In the event that the employee is assigned to perform additional works, he or she shall be paid for each additional working hour an overtime equivalent wage up to $125 \%$ of his usual daily wage and up to $150 \%$ of his usual wage for every working hour on weekends, holidays and public holidays." Article 8 of the above instructions state that: "for the purpose of calculating the value of overtime work, the allowance for additional assigned work shall not be considered as a part of the ordinary wage mentioned in item (1) above."

Meanwhile, Article 58 of the Jordanian Labor Law provides that: "The provisions of the Articles relating to the work hours provided for in this Law shall not apply to persons who assume the general supervision over the institution or its management as well as the workers whose business requires travel and movement inside or outside the Kingdom."

Some wages shall not be included by the monthly wage concept, namely: overtime, annual grants, gratuities and donations received by the insured from the clients and the allowance for representation; that is, the allowance paid to the insured who represents his employer at another party inside or outside the Kingdom. This also includes clothing, food and hospitality allowances. In addition, the commissions' percentages paid to the insured person in case of achieving certain targets of income and profit as well as bonuses and incentives that do not bear the status of stability and allowances as well as cash allowance paid for due holidays and children's education allowance and the remuneration of the Board of Directors and for the membership of committees and allowance for travel tickets, commissioners and secretaries of committees, secretaries, trustees' councils and telephone allowances. ${ }^{1}$ (Article (11) of the Regulation no. 119 for 2016).

Others add another condition, which is age. Where the Social Security Law determined a minimum age of (16) years for a worker compared with (18) years old under the provisions of the Labor Law. Accordingly, we conclude that the Social Security Law's scope is broader than the Labor Law's. Legislators realized the need to protect the worker younger than 16 years old and the trainee. (Obeidat,1998, p 21-22).

\section{Public employees who are not subject to the Civil Retirement Law}

\section{Unclassified Employee}

The Social Security Law includes unclassified employees defined in Article 2 of the Civil Retirement Law by stating that: "An employee who is appointed to a position with a salary specified in the Budget Law and does not have a degree, including all those who have previously been appointed as unclassified employees of a classified job, and have not been classified, but it does not include persons who are employed by the Government at the expense of open allocations or at the expense of project or deposit allocations with broken salaries on a daily basis or other wages."

${ }^{1}$ (The amendment of the Coverage of Social Security Corporation' Insurances Regulation issued under the provisions of Article (106) of the Social Security Law). 
The employee according to a specific contract at a Government job who is not subject to the Civil Retirement Law

This refers to employees contracted with the Government who may be covered by the Social Security Law for a specific period of time because they are basically not considered civil service employees, and paragraph (D) has excluded staff members appointed under contracts who under their terms have been subject to retirement.

\section{Employees as military servants who are not subject to the Military Retirement Law}

This law includes the military and all security services such as civil defense, intelligence, preventive security, criminal investigation, public security, and other similar jobs. Paragraph (A) of Article 3 of the Military Retirement Law states that "this law shall apply to Jordanian officers and soldiers except those who serve under a contract that does not entitle them to the right of retirement." In the meaning of the opposite, the Social Security Act can apply to all civil servant associates or those who work at unclassified jobs in the military departments, provided that they are not covered by contracts under which they are subject to the retirement system of these military departments.

Jordanians working in regional and international missions, political and military Arabic and foreign missions working in the Kingdom and its technical and educational centers

This refers to those who are covered by the Social Security Law in Article 4, paragraph 3, provided that they are not subject to the provisions of the Civil or Military Retirement Law and that they should not be diplomats. For example, a Jordanian who works in a regional, international, political or military mission, either a local or a foreign mission in the Kingdom, is covered by the Social Security Law if he or she is not subject to civil or military retirement laws.

\section{Self-employed, employers and joint partners working in their own enterprises}

"Self-employed" means the employer, the joint partner and the owner of the individual enterprise working in their own enterprises. (Article (40) of the Regulation no. 119 for 2016) The Social Security Corporation has started to cover such persons by social security since 1/1/2015.

The compulsory registration of an employer or a joint partner is only for employees of their premises, under certain conditions including to reach a minimum of 16 years of age and shall not exceed the age of 60 years old for the male and 55 years old for the female and to have no benefit from the retirement before $1 \backslash 1 \backslash 2015$. In the opposite concept, if the employer or the joint partner does not work in his own establishment, he or she shall register his workers at the social security, and he can personally contribute to the Social Security if he is Jordanian. In addition, if the employer and the like person owns more than one establishment and can prove he works in each of them, then it is not permissible for him to be covered by social security except in one establishment. In this case, he is entitled to determine the establishment that he wishes to be covered by social security upon his work in the first time he is covered by the law. (Paragraph (C) of Article (41) of the Regulation no. 119 for 2016).

On the other hand, the Social Security Corporation must cease the insured's coverage as an employer and the like when he withdraws from his or her establishment, closes it officially or discontinues his activities at such establishment. (Paragraph (D) of Article (41) of the Regulation no. 119 for 2016 ) As for the corporate partners, the social security obligation was imposed from $1 / 1 / 2015$ to provide them with safety and social protection. ${ }^{2}$

\footnotetext{
${ }^{2}$ Awareness leaflet issued by the Media Center of the Jordanian Social Security Corporation, 2015. p: 17.
} 


\section{Minors and trainee workers}

Article 2 of the Jordanian Labor Law defines the minor as: "Every male or female who has reached the age of seven and has not attained the age of eighteen years." We note that those covered by the Social Security Law are those who have completed 16 years old. However, the purpose of this is the inclusion of minors by the Social Security Law, as this Law is more beneficial to workers in general, so it is fair to include this vulnerable category (minors who have completed 16 years of age and not yet reached puberty) to be covered by the Law.

However, a trainee is the worker who is subject for preparation for the future, and a trainee worker shall be considered a permanent worker during his training time. The trainee is also defined as: "the natural person who did not complete (16) years old who is training at an establishment included by the provisions of law according to a training contract issued by the Vocational Training Corporation".( Article (12/A) of the Insurance Benefits of the Corporation No. 15 of 2015).

It is worth mentioning that Article 73 of the Labor Law prohibits the employment of a minor who has not completed the age of sixteen years and excludes the trainee juveniles. The Article states that "Subject to the provisions concerning vocational training, the minor who has not attained the age of 16 years may not be employed in any way." Whereas Paragraph (C) of Article 36 of the Labor Law stipulates that "a trainee who has completed 18 years old shall undertake the contract himself, or if he is a minor then his guardian or his in loco parentis shall represent him", i.e. the consent of the guardian or the in loco parentis of the minor is required upon the training. Article 5 (A) of the Social Security Law includes trainee workers by stating that: "the provisions of this law relating to the insurance of work injuries shall apply to trainees who have not completed sixteen years old in accordance with the regulations issued under the provisions of this Law, without charging any contributions by the establishment."

It is noted from the above Article that the trainees are covered by the provisions of the Social Security Law through the possibility of work injuries insurance. The above Article stipulates that the worker should be under 16 years and of course it is wise to protect such vulnerable minors in a trainee group from being exposed to any kind of injuries and occupational diseases (in particular), i.e. this category is not included by all the insurances of the Social Security Law such as disability, death, old age and so forth. Of course, including this category in the Social Security Law, during training in certain areas, will relieve them of any risks during training. It is also fair to include the trainee worker (minor) by other insurances such as death and disability, and certainly not to offer the trainee minor other insurance such as aging and maternity.

Article 5 of the Social Security Law includes some provisions concerning the trainee worker. Such as in Paragraph (B) which states: "If the trainee suffered permanent total disability or died as a result of a work injury, he shall be entitled to a monthly salary equal to the minimum determined for the disability pension or retirement pension." However, Paragraph (C) states: "If a trainee suffered a permanent partial disability resulting from a work injury, he shall be entitled to compensation equal to the proportion of that disability to the pension referred to in paragraph (B) of this Article for thirty-six months." Finally, Paragraph (D) provides that: "the definition of (insured) included in Article 2 of this law applies to the trainee who completed the age of sixteen years."

\section{Excluded categories from the Jordanian Social Security Law}

Article 4 of the Social Security Law states that the following categories shall not be subject to the provisions of this law:

Persons who pay contributions in accordance with the provisions of the Civil Retirement Law or the Military Retirement Law 
In the latest amendments to the Civil Retirement Law, the scope of application of this law is set for all civil servants in the government departments or institutions, excluding those before 1995, where all employees who joined after that date were covered by social security, except for some employees with special grades. The scope of this law applied to all the military personnel until before $1 / 1 / 2003$, where all the military authorities and the similar ones joined social security except some categories in the military sector.

Article 4 of the Civil Retirement Law determines the employees who shall be entitled to a pension, where it provides: "the following employees shall be subject to pension:

(A) All Jordanian classified civil servants paid by the general budget as well as the public institutions' officials with financial and administrative autonomy who are transferred to a job classified under the civil service regulation in force and paid from its budget, provided that its rules shall not state that its staff service is not covered by retirement and provided that their previous service shall be included by Paragraph (i) of Article (5) of this law. They shall be entitled to retrieval of their due payments under the Social Security Law and upon clearance between their payables and pension contributions.

(B) Jordanian classified employees of the Agricultural Bank and the Agricultural Credit Corporation.

(C) Jordanian classified government employees and Agricultural Bank who were employed before the first of April 1941 and who were covered by the retirement system upon their employment.

(D) The employees appointed pursuant to contracts and were, under its conditions, covered by the retirement system.

However, as mentioned above, those not included, for example, are those who are contributing to military or civil funds, so they are not covered by the Social Security Law.

Non-Jordanian laborers who are working at the international and regional missions, diplomatic, political or foreign and Arabic military missions in the Kingdom and consulates and their affiliate technical and educational centers

In this category are Non-Jordanian persons working in regional and international missions, Arab and foreign political or military missions operating in the Kingdom as well as their technical and educational centers or consulates. The text of this Article shows us that the nationality of the person is effective when working at these missions, consulates, or technical or educational centers. Those who work in these institutions, if they are non-Jordanian, shall not be subject to the Jordanian Social Security Law, whereas if they are Jordanian, the law will apply to them. The reason behind this is clear; the foreigner who works in these missions, consulates or centers is sometimes represented by his country and is therefore covered by the international conventions governing the relations of foreign countries. On the other hand, the foreigner may be an international institution or body, thus subject to international conventions or agreements signed thereof, so it is natural that they are not included in the Jordanian Social Security Law.

\section{Workers who have irregular relations with their employers}

Paragraph 3 of Article 4 of the Social Security Law states that "workers who have an irregular relationship with their employer are not covered by the Social Security Law, bearing in mind that the relationship is considered to be regular in the following cases, under which the Social Security Law applies to them:

“(A) For a daily worker, if he works sixteen days or more per month.

(B) The hourly or freelancer worker who shall work by the hour, piece or transport or similar if he works sixteen days or more per month, regardless of the number of working hours, pieces or transfers per day.

(C) For a worker who receives a monthly wage regardless of the number of working days per month except for the first month of his employment, where the principle of sixteen working days or more working days shall be applied in a month." 
The Jurisprudence, however, set two criteria to verify if a working relationship between a worker and his employer is regular or not. The first criteria are the nature of the work. It is sufficient for the working relationship to be considered regular if the work carried out by the worker is within the nature of the professional activity practiced by the employer, regardless of how long it takes to work. For example, if a carpet manufacturer contracts with a worker who practices the same profession, the working relationship is regular, even if the contract period is less than six months. The second criteria is the length of time or period upon which the employer may contract with non-practicing workers, and for specific as well as certain periods for the worker to be considered regular. ( Abu Amro, 2010, p 107-108).

\section{Ceased Categories from the Jordanian Social Security Law}

(A) Article 3 of the Labor Law excludes house workers from the application of the Labor Law by stating that: "(A) Subject to the provisions of Paragraph (B) of this Article, the provisions of this Law shall apply to all workers and employers except public servants and municipal employees."

(B) "The provisions to which agricultural workers, house workers, cooks, gardeners, and others are subject shall be determined by virtue of a particular regulation issued for this purpose, provided that such regulation shall include the organization of their employment contracts, working hours, break times, inspection and any other matters related to their use."

\section{Houses servants (house worker)}

However, the Social Security Law ceased to include house servants by the work insurance until the issuance of a particular regulation under this law, where Paragraph (C) of Article 4 of the Social Security Law states: "Subject to the provisions of Article 3 of this Law, insurances may be applied to house servants and similar workers by a decision of the Cabinet upon the recommendation of the Council."

The mentioned Article states that "the permission is related to the issuance of a decision by the Cabinet upon the recommendation of the Council and regulates all matters related to their coverage by these insurances under the regulations issued under the provisions of the Jordanian Social Security Law. The house workers and those who are similar are under Regulation No. 90 of 2009, where the issuance of such a regulation is one of the pioneering steps to protect this vulnerable class.

Article 2 of the above-mentioned Regulation of house workers defines the worker who is included in this Regulation as a house worker, cook, gardener or the like, who works in the service of the homeowner on an ongoing basis. The same Article defines the homeowner as a natural person who uses a worker in his home. Also, the same Article states that the housework refers to "the work related to the normal practice of the family, which can be carried out by the family members themselves such as cleaning, cooking, ironing, preparing the food, caring for its members."

So, the category excluded from the scope of the Social Security Law are those who engage in work inside the home intended for private housing and should be a physical work related to the fulfillment of the personal needs of the employer or his family. However, the reason for exclusion of such category of workers is that they have a direct connection between them and their householder, rather than the term of the servant that has been used by Jordanian legislation, for such a person is aware of many of the affairs of the employer and his family and through this special relationship he or she can build bridges of trust between them, thus the parties do not need to be subject to the Social Security Law for regulating the relationship between them. Rather, we need to regulate public matters for such work, which requires particular legislation to regulate this particular relationship between both parties. This is what house workers and other like workers Regulation actually adopted, where this regulation defines the commitment of the employer or the homeowner towards the worker, and the obligations of the worker as well as the organization for working hours and holidays. The system also regulates the dispute settlement mechanism between the employer and the non-Jordanian servant through the formation of the Labor Committee for the 
Affairs of Non-Jordanian servants by the Ministry of labor. ( Article (9) of The Home workers, Cooks, and gardeners and the like Workers Regulation, No. (90) for the year 2009).

However, some believe that the meaning of the servants who are working in private homes or houses and are therefore not subject to the Social Security Law provided that they meet two conditions. The first condition is that the place of work should be in a house designed for private housing while the second condition is that the work is done manually to undertake the personal needs of the employer (owner) or his family, and thus if the above two conditions exist the Social Security Law shall not apply. ( Mansour, 1996. p144).

Therefore, those persons or workers in the shops or offices of engineers shall not be considered servants. On the other hand, a person may combine manual work and mental work, or they work inside and outside the home. In such case, in order to know whether he or she is subject to the Social Security Law or not, we look at the main work of his multiple works. If it is manual work, he shall be considered a servant and shall not be subject to social security; however, if his main work is mental, he or she is entitled to benefit from the Social Security Law. ( Kassem, 2010, p. 57-58).

Thus, house servants are those persons who work at private houses for the purpose of assisting its householders in their daily activities. Where their works are characterized by privacy such as an attendant, cook or steward while mental works such as a private secretary, private librarian or private teacher, even if he or she did not practice their work inside the home. ( Bilal, 2009, p. 47) Furthermore, those who serve outside homes are also excluded from the servants' category, for example, persons who serve in hotels, restaurants, lawyers' offices and nurses working at medical clinics. (Al-Lamsawi J. \& Al-Helmawi, 2004, p. 84- 85).

\section{Other workers similar to home servants}

This category refers to those workers who work for the employer but are working outside the home and usually do personal work for the employer or his or her family, such as a guard, a doorman or a driver. In reference to the Home Workers Regulation, which includes cooks, gardeners, and other similar workers, we find that the legislation has given special provisions that may not be consistent to what is applicable to both the Labor Law and the Social Security Law. For example, paragraph A of Article 6 of this Regulation indicates that the total times in which the home worker actually may work shall not exceed ten hours a day excluding the time spent by the worker for his or her break, rest or eating. However, this is contrary to the provisions of the Jordanian Labor Law, which determines the period of work to be eight hours daily and in any case, the working period shall not exceed 48 hours per week. Also, Paragraph B of Article 6 of this Regulation, stipulates that "the owner of the house shall regulate the times of the worker's duties during the day as required by the nature of the assigned work and the needs of the house." However, Paragraph C of Article 6 of this Regulation states: "The worker shall be entitled to sufficient hours of sleep daily provided that it shall not be less than eight hours per day." Therefore, it should be noted that these provisions are based on special criteria based on the nature of the working relationship between the employer and the house worker.

Article 7 of the same Regulation provides that "The worker has the right to a weekly holiday that shall be agreed upon between him and the owner of the house. If the owner of the house is forced to assign the worker to work on his weekly holiday, he shall compensate him by another day agreed between them." Thus, it appears that the employer's obligation is not to pay additional wages in excess of the normal wages as stipulated in the Labor Law and that the rule here is to compensate him by another day instead.

\section{Pension systems in Jordan and the categories covered by each system}

According to the current Jordanian legislation, there are three systems for granting pensions to the insured. These are the general pension schemes that include: 
1- The general pensions system, which includes Social Security (the subject of this research), the Civil Retirement Security (which includes government employees) and the Military Pension System (which includes military as well as the security institutions personnel).

2 - The Jordanian Associations Pension Systems, such as the engineers, lawyers, doctors, and others.

3- Retirement schemes contracted by the insured with insurance companies.

And of course there are the provisions and mathematical equations used in calculating the pension under each system within these systems based on the laws and regulations thereof. The application of these systems is regulated by a social solidarity system, by the contribution of the insured and the employer, whether from the private or public sector, through the investment of contributions paid, and certainly this organization under the umbrella of the government through the enactment of laws and regulations.

Jordan is currently aiming to unify the work of these systems by combining them within a single system to be applied to all categories of the insured workers without disparity, thus becoming a unified system of social security, which would actually be adopted by some countries.

The Hashemite Kingdom of Jordan has come a long way towards unifying the pension security into a single system. This is considered to be favorable and compatible with development. All the insured workers are contributing to the Social Security Corporation. Accordingly, Jordanian laws moved most employees under civil and military retirement to the Social Security Laws and regulations. The remainder of those covered by civil and military retirement schemes are minor, and they will be terminated during the coming period. Also, all government employees, military personnel and employees in the private sector shall be covered by the Social Security Laws.

\section{Conclusion}

This study has discussed the category of workers who are mandatorily covered by the Jordanian Social Security Law as well as the category excluded from the scope of social security. As a result of the review of the Jordanian laws, it has been shown that these categories are the workers subject to the provisions of the effective Labor Law; they are the dependent workers who are paid by their employers for their work and are subject to social security. On the other hand, those workers who were employed as public servants or employees and who are not subject to the civil or military retirement law as well as Jordanian citizens working for regional and international missions and Arab political or military missions working inside the Kingdom as well as its affiliated technical consulates and centers fall under this category. Furthermore, among the categories subject to social security are minors and trainee workers. We have shown, in this research, that there are some workers categories that have been excluded from the coverage of the Jordanian Social Security Law such as house servants and other similar workers, except in certain cases and conditions. Finally, we have concluded that there are several pension systems, such as Social Security, civil retirement, military retirement and pension schemes provided by private insurance companies. Finally, we have discussed the overlapping of these systems with each other, and we have identified the categories included in the Social Security System.

\section{References}

Abu Amro M. (2010). Principles of the Social Insurance Law. Beirut, Lebanon: Al-Halabi Legal Publications.

Al-Lamsawi J. \& Al-Helmawi A. (2004). Encyclopedia of the New Labor Law, Volume I. Amman, Jordan: Imad House for the legal books distribution.

Al-Zoubi M. (2013). Social Security, Protection of the Elderly between the Market Economy and Social Justice. Amman, Jordan: Dar Wael for Publishing and Distribution.

Amin, N. S. M., Aziz, N. A., \& Ab Hamid, Z. (2017). Limitations of Social Security Laws and Policies Vis-A-Vis Migrant Workers in Malaysia. Journal of Malaysian and Comparative Law, 44(2), 27-44. 
Bilal A. (2009). The Labor Encyclopedia. Cairo, Egypt: Alaa Eddin Press.

Djankov, S., \& Ramalho, R. (2009). Employment laws in developing countries. Journal of Comparative Economics, 37(1), 3-13.

Hamdan H. (2009). Social Security Provisions and Applications Lebanon, Beirut: Al-Halabi Publications.

Jordanian Labor Law No. 8 of 1996.

Kassem M. (2010). Explanation of Social Insurance, Basic Rules and Complementary regulations . Alexandria, Egypt: University Publications House.

Mansour M. (1996). Social Insurance Law. Alexandria, Egypt: Al-Ma'arif Establishment.

McCrudden, C. (2017). Legal research and the social sciences. In Legal Theory and the Social Sciences (pp. 149-167). Routledge.

Obeidat A. (1998). Explanation of Social Security Law. Amman, Jordan: Dar Wael for Publication.

Ramadan S. (2014). Al-Waseet in explaining the Labor Law and the Social Security Law. Amman, Jordan: Dar Al-Thaqafa for publication and distribution.

Regulation of coverage of the General Organization for Social Security and its amended regulation No. (119) for the year 2016.

Tyler, T. R. (2017). Methodology in Legal Research. Utrecht Legal Review. 13, 130.

The Jordanian Social Security Corporation.( 2015). Awareness leaflet issued by the Media Center ,.

The Jordanian Civil Law No. (43) for the year 1976.

The Jordanian Social Security Law No. 1 of 2014 and the insurance regulations issued thereunder.

The Civil Retirement Law of 1959.

The Home Workers, Cooks and Gardeners and the like Workers Regulation, No. (90) for the year 2009.

The Insurance Benefits of the Corporation No. 15 of 2015.

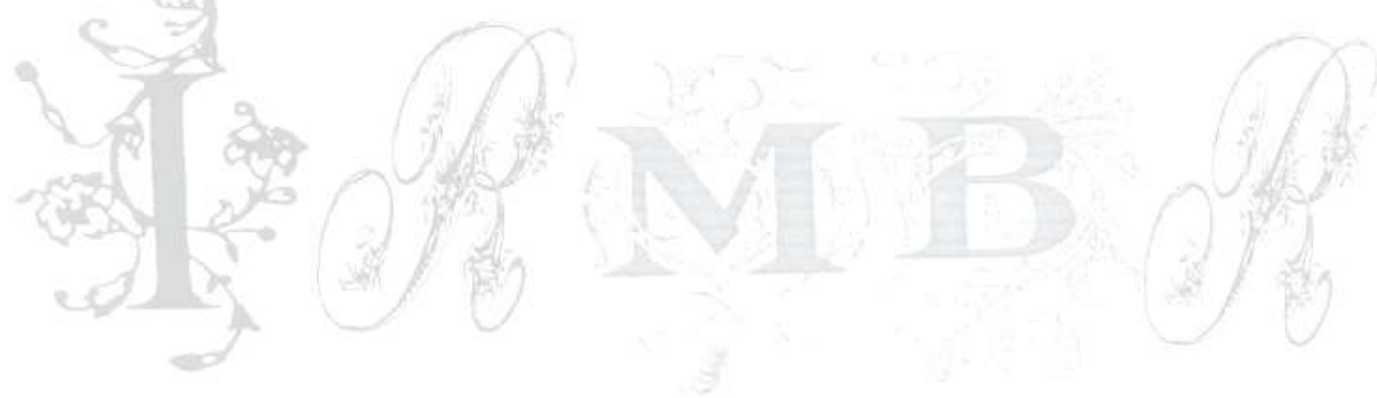

